\title{
International Worker Remittances and Economic Growth in a Real Business Cycle Framework
}

\author{
Michael Batu (University of Windsor)
}

Working paper $17-01$

Working papers are in draft form. This working paper is distributed for purposes of comment and discussion only. It may not be reproduced without permission of the copyright holder. Copies of working papers are available from the author or at http://ideas.repec.org/s/wis/wpaper.html. 


\title{
International Worker Remittances and Economic Growth in a Real Business Cycle Framework ${ }^{\hat{k}}$
}

\author{
Michael Batu \\ Department of Economics, University of Windsor, Windsor, Ontario, N9B 3P4, Canada
}

\begin{abstract}
In this article I augment the standard open economy Real Business Cycle (RBC) model with stochastic remittance shocks. The model was calibrated to match broad, stylized facts common across a large set of remittance recipient countries. The calibration exercise reveals that output does not respond as much to remittance shocks relative to technology shocks. The model predicts that temporary inflows of worker remittances positively affect GDP per capita while a permanent increase of remittances does not. Cross country econometric evidence is consistent with the theory: there is a significant and positive correlation between the temporary component of remittances and growth; and permanent component of remittances do not affect output growth.
\end{abstract}

Keywords: Remittances, business cycles, economic growth $J E L:$ F24, O11, E32

\section{Introduction}

Next to foreign direct investments and foreign aid, wealth transfers such as remittances constitute a significant source of foreign financing in developing countries (see figure 1). The common wisdom is that these transfers are generally spent on consumption goods thus helping recipients improve their welfare. However, beyond improving the welfare of its recipients, the effects of remittances on aggregate economic performance is not well understood. Previous research in remittance effectiveness generally found mixed results and scholars have become skeptical about the developmental effects of remittances. ${ }^{1}$ Most of the current research in remittance effectiveness finds the absence of a causal relationship between remittances and economic growth (Barajas et al., 2009).

How come worker remittances do not appear to be effective in stimulating economic growth? To

\footnotetext{
${ }^{\text {in }}$ I am indebted to an anonymous referee for feedback. My thanks are due to Kurt Annen, Stephen Kosempel and Thanasis Stengos for useful discussions, as well as seminar participants in the University of Guelph and the CDESG meetings.

Email address: mbatu@uwindsor.ca. (Michael Batu)

${ }^{1}$ The differences in findings with respect to effectiveness of worker remittances are highlighted in a literature review by Fullenkamp et al. (2008).
}

answer this question, the current study complements the conventional approach of using crosscountry growth regression models to study the relationship between remittances and economic growth with an open economy Real Business Cycle (RBC) model. An open economy RBC model is appropriate because it can predict how agents will respond to exogenous remittance shocks, particularly their consumption, labor supply, and investment decisions. The idea is that remittances affect output through growth in economic aggregates such as investment, consumption, and trade, as well as changes in labor supply.

This article contributes to the literature in three respects: First, the theoretical component of this paper makes use of an open economy RBC model to evaluate the effectiveness of remittances to growth in GDP per capita. Through RBC models, it is possible to tease out the economic impact of worker remittances to GDP per capita from other types of shocks (like technology shocks). Second, this study contributes to the empirical literature on remittance effectiveness by adding permanent and temporary components of migrant remittances to variables that explain economic growth. Within the literature on remittances this paper is, to the best of my knowledge, the first to use such a decomposition as an explanatory variable 
to growth in GDP. Lastly, to calibrate the model, as well as for the regressions, data from the most number of recipient countries possible (81) and a long time horizon (1970-2012) was used.

This article has the following main results motivated by RBC theory: First, a permanent change in worker remittances does not affect output in the long run. The idea is that a permanent change in worker remittances produces a positive income effect, and since leisure is a normal good, hours worked falls. A reduction in hours worked is followed by a reduction in output. Second, a temporary change in worker remittances produces a positive effect to output in the short run. Agents want to maintain a smooth consumption profile in the face of a temporary change in worker remittances. This consumption smoothing behavior force agents to optimally save some of their remittances received leading to an increase in investment and output. To test these results empirically, a reduced-form regression model commonly used in the remittance effectiveness literature with the addition of permanent and temporary component of remittances was estimated. The findings suggest that the temporary component of worker remittances positively affect growth rates in GDP per capita, although the extent of this effect can be considered modest. On the other hand, the permanent component of remittances does not affect growth in GDP per capita. ${ }^{2}$

\subsection{Brief background literature}

The current study is closely related to two papers: Annen and Kosempel (2012) and Annen et al. (2016). In Annen and Kosempel (2012) they used a closed economy RBC model to evaluate the effectiveness of foreign aid. Their study found that temporary changes in aid have positive effects on growth. Also, they empirically test the effectiveness of aid to economic growth. In Annen et al. (2016) they evaluated the effectiveness of wealth transfers through a closed economy RBC model. They define wealth transfers to include remittances and foreign aid. They also

\footnotetext{
${ }^{2}$ The neutral effect of permanent wealth transfers is well known in the literature (e.g. Annen and Kosempel, 2012). However, what is different in this setting is that temporary remittance (as opposed to permanent) does have an impact on economic growth. One of my contributions is to empirically test this result for remittance recipient countries. Specifically, I decompose remittance to its permanent and temporary components, and test their effectiveness to economic growth.
}

found that a temporary change in wealth transfers produce positive effects on growth. My results are similar to these papers in the sense that a temporary change in remittances also produce a positive effect on growth. In addition, I followed their approach in calibrating the parameters of the model. Despite the similarities, the current study is different from these two papers in several respects: First, and importantly, the focus of their study is on foreign aid or wealth transfers while the current paper is exclusively about remittance effectiveness. Second, my study makes use of an open economy RBC model which offers a more realistic way to model the impacts of remittance flows. Third, in the empirical analysis I use different measures for permanent and temporary remittances. Annen and Kosempel (2012) decomposed aid into permanent and temporary components using linear regression approach. According to Pagan (1984) this approach may produce estimates that suffer from generated regressor bias. In the current study I instead use the HP filter to decompose remittance. And finally, Annen et al. (2016) provided a policy discussion on the role of wealth transfers to economic growth. In contrast, the current study makes use of a positive (as opposed to normative) approach as it is solely focuses on explaining the general equilibrium effects of remittances.

There are other studies that used RBC (or, in general, DSGE) models to study the effects of remittance fluctuations on the cyclical behavior of macroeconomic variables. Often, these studies focus only on a single country or a small group of countries with similar characteristics (i.e. developing or major remittance recipient countries). Chami et al. (2006) used a DSGE model to investigate the influence of countercyclical remittances on the conduct of fiscal and monetary policy and trace their effects on real and nominal variables. They found that remittances raise disposable income and consumption and insure against income shocks, thereby raising household welfare. Acosta et al. (2009) developed and estimated a two-sector DSGE model to analyze the effects of remittances on the economy of El Salvador. They found that an increase in remittance flows leads to a decline in labor supply and an increase in consumption demand that is biased toward non-tradables. Durdu and Sayan (2010) used a two-sector model of a small open economy with financial frictions calibrated to Mexico and Turkey. They found that effects of worker remittances in the long run 


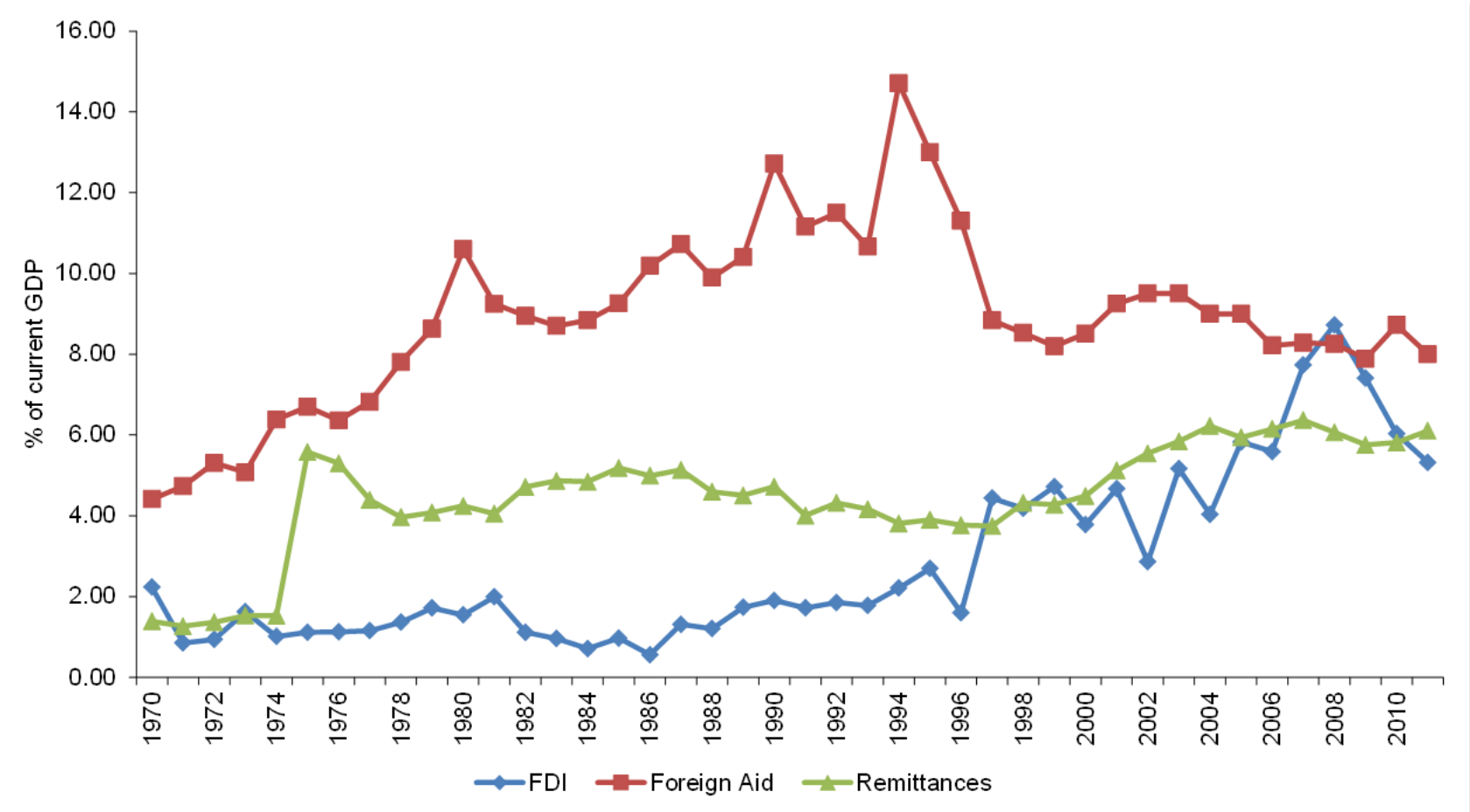

Figure 1: Net official development assistance, remittances and foreign direct investments, 1970-2010 averages in current US dollars (from World Development Indicators).

are mild. In the short run, however, remittances have quantitatively large impacts on the economy, when there are borrowing constraints. Mandelman (2013) constructed a heterogeneous agent model to analyze the role of monetary policy in a small open economy subject to sizable remittance fluctuations. He found that recipient households are better off with the exchange rate peg when facing an uptrend in remittances. Moreover, he was able to show that countercyclical remittances and a flexible policy regime pursuing stabilization goals are useful tools to smooth the consumption path of credit constrained households and achieve macroeconomic stability.

While there are studies that used calibration methods, those that use cross-country growth regressions nonetheless dominate the current literature on remittance effectiveness. Several studies stand out from this strand of literature. One of the early studies is by Chami et al. (2003) where they used cross-section and panel data of 113 remittance recipients for 29 years (1970-1998). They found that the share of remittance to GDP is, at best, not a significant variable in explaining GDP per capita growth. According to them remittances are negatively correlated economic growth because of a moral hazard problem. Due to remittances, recipients can decrease their labor force participation, limit their job searches, reduce labor effort or engage in risky ventures. These results were later supported by Rao and Hassan (2012) which found that direct growth effects of remittances as measured by share of remittance to GDP are insignificant. Their results were robust with alternative specifications and estimation methods.

Faini (2006) used a cross section of 68 countries in which the dependent variable is the average annual per capita GDP growth rate from 1980 to 2004. He found a positive and significant relationship between total remittances and economic growth. However, using an instrumental variable approach with distance between countries as an instrument, the coefficient for total remittance lost its significance but remained positive.

Another paper that used total remittances as an explanatory variable is Giuliano and Ruiz-Arranz (2005). They used a panel of 73 countries from 1975 to 2002 . Their basic specification regressed per capita GDP growth on the ratio of total remittances to GDP with the initial level of GDP per capita, the investment rate, population growth, the fiscal balance as a percentage of GDP, years of education, openness, and inflation as explanatory variables. Their specification did not find evidence that total remittances is significantly related to growth.

Catrinescu et al. (2009) covered 114 countries 
during the 1991-2003 period and included institutional variables into their analysis. Overall, their study found a positive relationship between growth in GDP per capita and gross capital formation, as well as between growth and some of the institutional variables. Their study also found some evidence of a mild positive relationship between growth and total remittances.

In a cross-country study with 84 recipient countries and a longer time period (1970-2004), Barajas et al. (2009) found that remittances do not seem to make a positive contribution to economic growth. Their study was different in two respects: First, they constructed a new instrument which is the ratio of remittances to GDP of all other recipient countries. Second, a trade-weighted average growth rate of real per capita GDP of the remittance-receiving country's top 20 trading partners was added as an explanatory variable. Their findings were consistent with criticisms of foreign aid by Rajan and Subramanian (2008) that there is very little evidence that decades of official transfers have contributed much to the growth of developing economies.

The rest of this paper is organized as follows. Section 2 presents the model with stochastic remittance shocks. A simplified version of the model in the steady state is presented in section 3 . Section 4 presents and discusses the calibration and simulation results. Section 5 presents the empirical model and regression results. Section 6 concludes.

\section{Canonical small open economy RBC model with remittances}

The model economy discussed below has the basic structure of the standard small open economy RBC model with the addition of remittance shocks. $^{3}$ Time is discrete and indexed by $t=$ $0, \ldots, \infty$. Variables with a bar denote a steady state value.

The economy is populated by a large number of identical infinitely-lived agents. The expected lifetime utility, $U$, of the representative agent is defined as:

$$
E_{0} \sum_{t=0}^{\infty} \beta^{t} U\left(c_{t}, l_{t}\right)
$$

\footnotetext{
${ }^{3}$ With the exception of remittances, the discussion in this section follows the small open economy model described in Schmitt-Grohe and Uribe (2003) and Mendoza (1991).
}

where $U$ is the period utility function, $\beta>0$ is the degree of time preference, $c_{t}$ represents consumption and $l_{t}$ represents leisure. Agents are endowed with one unit of time which can be allocated between leisure and work, $n$.

The economy produces an internationally tradable composite commodity using inputs of capital, $k$, and labor, subject to a neoclassical constant returns to scale technology:

$$
G\left(k_{t}, n_{t}, k_{t+1}\right)=z_{t} f\left(k_{t}, n_{t}\right)-\Phi\left(k_{t+1}-k_{t}\right)(2)
$$

where $z_{t}$ is a random productivity shock and $\Phi\left(k_{t+1}-k_{t}\right)$ is the cost of adjusting the capital stock as a function of net investment. ${ }^{4}$ The function $\Phi(\cdot)$ is assumed to satisfy $\Phi(0)=\Phi^{\prime}(0)=0$ thereby ensuring that in the non-stochastic steady state adjustment costs are zero and the domestic interest rate is equal to the marginal product of capital. $^{5}$ The random productivity shock is assumed to follow an $\mathrm{AR}(1)$ process:

$$
\ln z_{t}=\left(1-\xi_{z}\right) \ln \bar{z}+\xi_{z} \ln z_{t-1}+\varepsilon_{z, t}
$$

where $\left|\xi_{z}\right|<1$ and $\varepsilon_{z} \sim N\left(0, \sigma_{z}^{2}\right)$.

Similar to Mendoza (1991), agents have access to a perfectly competitive international capital market in which foreign assets $b$, that pay or charge the real interest rate $r$, are exchanged with the rest of the world. The law of motion of foreign asset holdings is expressed as:

$$
b_{t+1}=t b_{t}+\left(1+r_{t}\right) b_{t}
$$

where the trade balance, $t b$, reflects the net flow of the good between the small open economy and the rest of the world. Following Nason and Rogers (2006) I assume that the real interest rate is given by:

$$
r_{t}=r^{\star}+p\left(b_{t}\right)
$$

where $r^{\star}$ denotes the world interest rate and $p\left(b_{t}\right)$ is a country-specific interest rate premium. For simplicity I assume that the risk premium is strictly increasing and the world interest rate is constant. Two reasons motivate the assumption

\footnotetext{
${ }^{4}$ As in Mendoza (1991) this model ignores the existence of non-traded goods and the substitution effects induced by changes in relative prices of the traded non-traded commodities.

${ }^{5}$ This configuration of capital adjustment costs avoids excessive volatility in investment as a result of variations in domestic and world interest rates.
} 
of a bond-elastic interest rate: First, it can capture the presence of financial frictions; And second, it gives rise to a steady state of the model that independent of the initial net foreign asset position of the economy. ${ }^{6}$

Disposable income in the economy may be allocated to consumption, foreign asset holdings, or investment $i$. Since residents in the economy being modeled are assumed to receive remittances $d$ from migrants abroad the appropriate resource constraint is given by:

$$
z_{t} f\left(k_{t}, n_{t}\right)+d_{t}=c_{t}+i_{t}+\Phi\left(k_{t+1}-k_{t}\right)+t b_{t} \cdot(6)
$$

From the resource constraint one can see that remittances enter as a form of wealth transfer. While it is acknowledged that there many forms of wealth transfers, this paper consider a specific form where wealth is passed from a family member to a relative in the home country. Remittances are tied to the country's stock of migrants abroad which for simplicity is assumed to be exogenous and embodied in $d$. The remittance term is additive (as opposed to multiplicative) to output to reflect the fact that international remittances augment the income of their recipients. ${ }^{7}$ Similar to the productivity variable remittances is assumed to follow an $\mathrm{AR}(1)$ process:

$$
\ln d_{t}=\left(1-\xi_{d}\right) \ln \bar{d}+\xi_{d} \ln d_{t-1}+\theta \varepsilon_{z, t}+\varepsilon_{d, t}(7)
$$

where $\left|\xi_{d}\right|<1, \theta \in \mathbf{R}$ and $\varepsilon_{d} \sim N\left(0, \sigma_{d}^{2}\right)$. The parameter $\theta$ is included to capture the relationship that may exist between remittance levels and the state of economic conditions in the recipient country (Annen and Kosempel, 2012). If $\theta$ is positive, then the recipient country will receive an increase in remittances when economic conditions are good. However, $\theta$ may also be negative, and in this case the economy will receive relatively more remittances during periods where productivity and output are low. ${ }^{8}$

\footnotetext{
${ }^{6}$ Schmitt-Grohe and Uribe (2014) notes that "equilibrium in a small open economy is non-stationary in consumption, trade balance, and foreign asset holdings, thereby complicating the task of approximating equilibrium dynamics". Stationarity can be induced by, among other devices, introducing a bond-elastic interest rate (e.g. Nason and Rogers, 2006) or an endogenous discount factor in the utility function (e.g. Mendoza, 1991).

${ }^{7}$ The model can have features where remittances can be used to improve productivity of inputs (like a multiplicative remittance shock) or where migration is endogenous. However, such features are beyond the scope of this study.

${ }^{8}$ There is empirical evidence which suggest that countercyclicality is not commonly observed among remittancereceiving countries (Sayan, 2006).
}

Finally, the law of motion of capital is given by:

$$
k_{t+1}=i_{t}+(1-\delta) k_{t}
$$

where $\delta$ denotes the depreciation rate of capital.

The Social Planner seeks to maximize the expected lifetime utility of the representative agent by choosing the optimal sequences $\left\{c_{t}, n_{t}, y_{t}, i_{t}, k_{t+1}, b_{t+1}\right\}_{t=0}^{\infty}$, subject to the resource constraint, the law of motion for capital, the law of motion for foreign assets, the production technology, the stochastic processes, and a no-Ponzi constraint: ${ }^{9}$

$$
\lim _{j \rightarrow \infty} E_{t} \frac{b_{t+j}}{\Pi_{s=0}^{j}\left(1+r_{s}\right)} \leq 0
$$

\section{Remittances in the long run: A special case with inelastic labor supply}

The steady state effects of remittances can be best studied in a simple, deterministic setting. A simple model allows one to study the effects of remittance flows on agents' savings and consumption decisions. The simplification was done in three ways: First, the period utility function is assumed to depend only on consumption and labor is supplied inelastically $(n=1)$. Second, the stochastic components are removed, thus $z_{t}=z^{*}$ and $d_{t}=d^{*}$. And third, capital mobility is restricted in a way that remittances are the only source of funds outside the model economy and there are no capital adjustment costs. With the exception of remittances, the simplified version of the benchmark model and the discussions in this section are identical to Annen and Kosempel (2012).

As a result of these simplifications one can easily find the Euler equation, the resource constraint and a transversality condition:

$$
\begin{aligned}
& \beta u^{\prime}\left(c_{t+1}\right)\left[\bar{z} f^{\prime}\left(k_{t+1}\right)+1-\delta\right]=u^{\prime}\left(c_{t}\right) \\
& k_{t+1}=\bar{z} f\left(k_{t}\right)+(1-\delta) k_{t}-c_{t}+\bar{d} \\
& \lim _{t \rightarrow \infty} u^{\prime}\left(c_{t}\right) k_{t}=0
\end{aligned}
$$

\footnotetext{
${ }^{9}$ Since there are no externalities and other market imperfections, the competitive equilibrium in this economy can be calculated as the solution to the Social Planner's problem.
} 


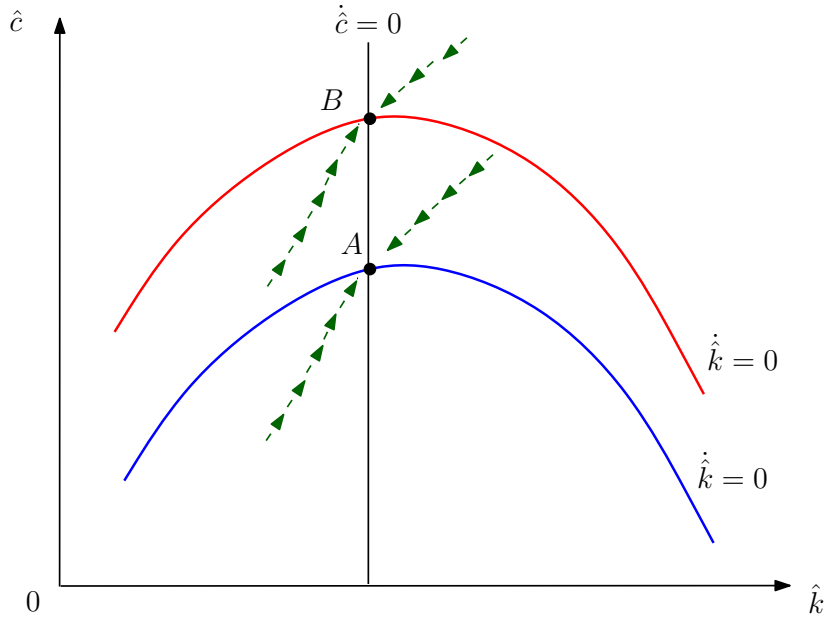

Figure 2: Effects of a permanent increase in international worker remittance flows.

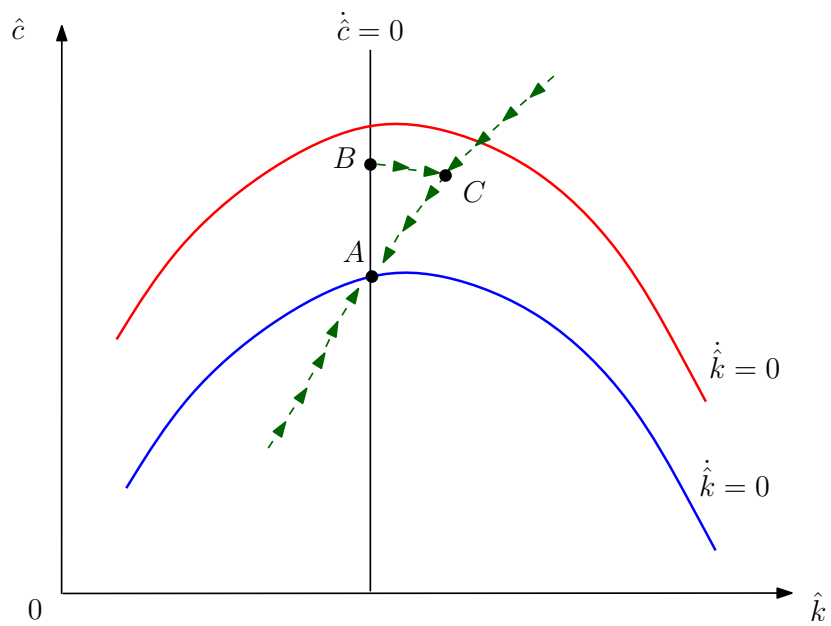

Figure 3: Effects of a temporary increase in international worker remittance flows.

Since the general properties of the model are wellknown, the discussion will focus only on the dynamics of the model after a change in the remittance parameter $\bar{d}$. In the steady state, equations (10) and (11) become:

$$
\begin{aligned}
& \bar{z} f^{\prime}(\bar{k})+1-\delta=\frac{1}{\beta} \\
& \bar{c}=\bar{z} f(\bar{k})-\delta \bar{k}+\bar{d}
\end{aligned}
$$

The phase diagram of the dynamic system in the $c$ and $k$ space is presented in figure 2. Suppose initially that the economy is at a long run equilibrium at point $\mathrm{A}$ and does not receive remittance, $\bar{d}=0$. Now suppose there is an unanticipated inflow of remittances that is expected to be permanent, $\bar{d}>0$. The Euler equation is independent of remittance so it will not shift. However, the unanticipated permanent remittance shock will shift the resource constraint upwards. The extent of the shift in the resource constraint will depend on the size of the remittance. Once the inflow of remittances arrive the saddle path instantaneously shifts and the new long run equilibrium is achieved at point B. A permanent increase in remittances produces two effects: First, there will be an increase in steady state consumption; and second, the level of steady state capital is unchanged. ${ }^{10}$ Agents will want to smooth their consumption profile faced with a remittance shock that is permanent. Thus, they consume all of the remittance per period after the change and leave nothing for saving. Since the saving rate associated with a permanent change in remittance is zero, it will not be effective in raising output per capita. ${ }^{11}$

Suppose now that the increase in remittances is temporary and its terminal date is known with certainty. The transitional dynamics of a temporary increase in remittances and its macroeconomic effects is shown in figure 3. Given the unanticipated remittance inflows the level of consumption increases to point B. The size of the jump from points $\mathrm{A}$ to $\mathrm{B}$ depends on how long the temporary remittance is expected to last. If remittance is expected to last for a very short period of time then most of the remittance inflow will be saved and the increase in consumption will be very small. This leads to a temporary increase in capital at point $\mathrm{C}$. On the other hand, if the remittance inflow is expected to last for a long period of time, marginal propensity to save will be low and much of the remittance will be consumed. These explanations follow the permanent income hypothesis: Given a temporary increase in remittance, agents must optimally invest some of the remittances received to maintain a smooth consumption profile. Over time, the remittance slowly runs out and the economy reverts back to its initial equilibrium in point $\mathrm{A}$.

The restricted version of the model provides a good framework to describe the long run effects of remittances. However, it does not allow one to

\footnotetext{
${ }^{10}$ It should be recognized that remittances may not necessarily have neutral effects when agents substitute remittances for credit which is a common situation in developing countries. In the face of binding borrowing constraints agents will not be able to invest up to their optimal capital stock level. Many thanks to an anonymous referee for pointing this out.

${ }^{11}$ Output may decrease if leisure is included in the model. This result stems from standard macroeconomic intuition that since leisure is a normal good, leisure rises in the face of an unanticipated inflow of remittance. Consequently, hours worked drops as well as output per capita.
} 
properly quantify the effectiveness of remittances because there is no uncertainty and its impact differ across countries. To better quantify the effects remittance have on macroeconomic performance, we revert back to the stochastic version of the model and proceed to the calibration exercise.

\section{Calibration and simulations}

\subsection{Data and business cycles}

I follow the World Bank definition of worker remittance as the sum of personal transfers and compensation of employees. ${ }^{12}$ Data for worker remittance was obtained from the World Development Indicators database. Data for other macroeconomic aggregates were sourced from the Penn World Tables and UNCTAD database.

Following Kydland and Prescott (1990), business cycles are defined as the deviations of macroeconomic aggregates (i.e. output, consumption, investment, trade balance, remittance) from trend, and business cycle facts are the statistical properties of co-movements of these aggregates with respect to deviations from trend of GDP per capita. When examining business cycle aspects of the data, each data series was detrended using the Hodrick and Prescott (1981) HP filter. For any series $x_{t}$ for $t=1,2, \ldots, T$, the HP filter extracts a trend component $\tau_{t}$ and a cyclical component $s_{t}=x_{t}-\tau_{t}$ by minimizing the loss function:

$$
\sum_{t}^{T}\left(x_{t}-\tau_{t}\right)^{2}+\lambda \sum_{t}^{T-1}\left[\left(\tau_{t+1}-\tau_{t}\right)-\left(\tau_{t}-\tau_{t-1}\right)\right]^{2}(15)
$$

where $\lambda$ is a weight that reflects the relative variance of the two components. Since remittances data are available annually the parameter $\lambda$ was set to 6.25 following Ravn and Uhlig (2002). Data were expressed in logs to capture percentage deviations from trend. Following Baxter and King (1995) the first and last observations were dropped prior to calculating the moments of the business cycle components. This ensures that the results are not influenced by behavior in the endpoints of the filtered series. Finally, contemporary

\footnotetext{
${ }^{12}$ Personal transfers include all current transfers in cash or in kind between resident and nonresident individuals, independent of the source of income of the sender and the relationship between the households. Compensation of employees represents remuneration in return for the labor input to the production process contributed by an individual in an employer-employee relationship with the enterprise.
}

cross-serial correlations of the cyclical components of remittance and output were computed. As is customary in the macroeconomic literature, a positive contemporaneous correlation implies that remittances are procyclical and a negative contemporaneous correlation as countercyclical. Following Pallage and Robe (2001), correlation is judged to be non-different from zero if it lies in the interval $(-0.29,0.29)$.

Table 1 reports the standard deviations and cross serial correlations of output and other economic aggregate time series data for 49 remittance recipient countries. A recipient is excluded from table 1 if fewer than 20 consecutive years of data are available for that country. However, for the regressions there were 81 recipient countries included in the sample. As shown in table 1, investment and remittances are four and almost ten times more volatile than output, respectively. There is not much difference between GDP and GNP in terms of volatility. Consumption is more volatile than output which suggest difficulty in consumption smoothing, a stylized business cycle fact among developing countries (Rand and Tarp, 2002; Annen et al., 2016). Remittance is ayclical for 35 countries (or $71 \%$ ) in the sample. Trade balance is slightly more volatile than output and is weakly countercyclical. Also reported are business cycle statistics according to the share of remittance to output of recipient countries. Remittances are more volatile for recipient countries that receive little of it (less that $1 \%$ of output). There is not much difference in business cycle statistics across other economic aggregates for remittance recipients.

\subsection{Calibration}

To quantify the model one must specify functional forms to be used in the simulations. This study abides by the common practice in the macroeconomic literature and specify the utility function to be:

$$
u\left(c_{t}, l_{t}\right)=\frac{\left(c_{t}^{\omega} l_{t}^{1-\omega}\right)^{1-\gamma}}{1-\gamma}
$$

where $\gamma>0$ is the coefficient of risk aversion and $\omega>0$ is the elasticity of substitution. The production function is specified to be Cobb-Douglas:

$$
y_{t}=z_{t} k_{t}^{\alpha} n_{t}^{1-\alpha}
$$


Table 1: Business cycle statistics from data for remittance recipients for the period 1970-2012.

\begin{tabular}{|c|c|c|c|c|c|c|c|c|}
\hline \multirow[b]{2}{*}{ Variable $(x)$} & \multicolumn{2}{|c|}{$\begin{array}{l}\text { All remittance } \\
\text { recipients }\end{array}$} & \multicolumn{6}{|c|}{$\begin{array}{l}\text { Share of remittances to GDP: } \\
\qquad 10 \%-1 \%\end{array}$} \\
\hline & $\sigma_{x}$ & $\rho_{x, G D P}$ & $\sigma_{x}$ & $\rho_{x, G D P}$ & $\sigma_{x}$ & $\rho_{x, G D P}$ & $\sigma_{x}$ & $\rho_{x, G D P}$ \\
\hline GDP & 2.78 & 1.00 & 2.16 & 1.00 & 2.85 & 1.00 & 2.92 & 1.00 \\
\hline GNP & 2.79 & 0.69 & 2.01 & 0.53 & 2.81 & 0.72 & 3.09 & 0.70 \\
\hline Consumption & 3.22 & 0.63 & 2.35 & 0.50 & 3.20 & 0.69 & 3.62 & 0.59 \\
\hline Investment & 12.13 & 0.58 & 8.72 & 0.44 & 13.56 & 0.56 & 11.43 & 0.67 \\
\hline Trade balance/GDP & 2.76 & -0.22 & 2.80 & -0.03 & 2.58 & -0.24 & 3.02 & -0.26 \\
\hline Remittance & 26.21 & -0.04 & 11.09 & 0.12 & 26.89 & -0.08 & 31.44 & -0.03 \\
\hline Remittance/GDP & \multicolumn{2}{|c|}{$4.0 \%$} & \multicolumn{2}{|c|}{$14.4 \%$} & \multicolumn{2}{|c|}{$3.6 \%$} & \multicolumn{2}{|c|}{$0.4 \%$} \\
\hline
\end{tabular}

Table 2: Model parameter values.

\begin{tabular}{lccccccccccccccccc}
\hline Parameter & $\bar{d}$ & $\gamma$ & $\alpha$ & $\delta$ & $\bar{n}$ & $r^{\star}$ & $\beta$ & $\omega$ & $\bar{z}$ & $\theta$ & $\xi_{z}$ & $\sigma_{z}$ & $\psi$ & $\xi_{d}$ & $\sigma_{d}$ & $\phi$ & $\bar{b}$ \\
values & 0.018 & 2 & 0.32 & 0.1 & 0.3 & 0.04 & 0.96 & 0.3495 & 1 & 0 & 0.81 & 0.162 & 0.01 & 0.61 & 0.628 & 0.05 & 0.74 \\
\hline
\end{tabular}

where $\alpha \in(0,1)$ is capital's share parameter. The capital adjustment cost function is assumed to be quadratic:

$$
\Phi\left(k_{t+1}-k_{t}\right)=\frac{\phi}{2}\left(k_{t+1}-k_{t}\right)^{2}
$$

where $\phi>0$. The specification of $\Phi(\cdot)$ implies that net investment, whether positive or negative, generates resource costs. Finally, following Schmitt-Grohe and Uribe (2014), the country interest rate premium takes the form:

$$
p\left(b_{t}\right)=\psi\left(e^{b_{t}-\bar{b}}\right)-1
$$

where $\psi>0$ and $\bar{b}$ are parameters.

The model will be simulated numerically following the method described in King et al. (1988) and Annen et al. (2016). As shown in table 2, parameter values are set so that the model's properties match averages from data for remittance recipients. The value for the elasticity of substitution parameter in the utility function $\omega$ was set such that the average time spent working $\bar{n}$ of $30 \% .{ }^{13}$ Similarly, the discount factor $\beta$ was set such that the average annual real interest rate $r^{\star}$ is $4 \%$. The steady state value in the stochastic process for remittances $\bar{d}$ is set to 0.018 which implies an average remittance-GDP ratio of $4 \%$ for the sample of countries. The parameters for standard deviations of the innovations in the stochastic processes, $\sigma_{z}$ and $\sigma_{d}$, were set to 0.162 and 0.628 ,

\footnotetext{
${ }^{13}$ In the RBC literature estimates for average hours worked varies from $1 / 5$ to $1 / 3$.
}

respectively, to match the average annual standard deviations for productivity and remittance shocks in the sample. For baseline calibration $\xi_{d}$ is set to 0.61 which represents the median value estimated from the sample of countries. ${ }^{14}$ In the remittance process a sensitivity analysis will be performed on the parameter $\theta$. For baseline calibration $\theta$ is set to zero which implies that the reason for giving remittances is independent to the state of economic conditions in the recipient countries. The parameters $\phi$ and $\psi$ were set to 0.053 and 0.01011 , respectively, to produce reasonable amount of standard deviations for investment and trade balance, as well as their correlations to output.

The next set of parameter values were selected on the basis that they have been previously used in the macroeconomics literature. The values for $\bar{b}, \gamma$ and $\alpha$ were set equal to $0.7442,2$ and 0.32 , respectively, following Schmitt-Grohe and Uribe (2003). The depreciation rate $\delta$ was set to $10 \%$ per annum. The value of the autocorrelation coefficient in the technology process $\xi_{z}$ is set equal to 0.81 , which is the annual equivalent to 0.95 , used for quarterly series by Prescott (1986). The steady state value of the productivity shock $\bar{z}$ only affect the scale of the economy and can therefore be normalized to 1 .

\footnotetext{
${ }^{14}$ Regression results for the autocorrelation coefficient in the remittance process has a sample mean value of 0.64 , a minimum value of 0.18 , a maximum value of 0.94 and a standard deviation of 0.16 .
} 
Table 3: Permanent changes in share of remittance to output per capita.

\begin{tabular}{|c|c|c|c|c|c|}
\hline \multirow[b]{2}{*}{ Steady state values } & \multicolumn{5}{|c|}{ Remittance to GDP ratio } \\
\hline & $0 \%$ & $1 \%$ & $4 \%$ & $10 \%$ & $20 \%$ \\
\hline Consumption/GDP & 0.778 & 0.786 & 0.809 & 0.863 & 0.916 \\
\hline Investment/GDP & 0.230 & 0.230 & 0.230 & 0.230 & 0.230 \\
\hline GDP & 2.037 & 2.024 & 1.980 & 1.895 & 1.816 \\
\hline Consumption & 1.585 & 1.590 & 1.602 & 1.635 & 1.663 \\
\hline Investment & 0.469 & 0.466 & 0.456 & 0.436 & 0.418 \\
\hline Hours worked & 0.313 & 0.311 & 0.304 & 0.291 & 0.279 \\
\hline
\end{tabular}

Table 4: Model economy business cycle statistics.

\begin{tabular}{|c|c|c|c|c|c|c|c|c|c|c|}
\hline \multirow[b]{2}{*}{ Variable $(x)$} & \multicolumn{2}{|c|}{$\begin{array}{l}\text { Productivity and } \\
\text { remittance shocks } \\
\text { (1) }\end{array}$} & \multicolumn{2}{|c|}{$\begin{array}{l}\text { Productivity } \\
\text { shocks only } \\
\text { (2) }\end{array}$} & \multicolumn{2}{|c|}{$\begin{array}{l}\text { Remittance } \\
\text { shocks only } \\
\text { (3) }\end{array}$} & Pro & $\begin{array}{l}\text { Direction } \\
\theta>0) \\
4)\end{array}$ & $\begin{array}{r}\text { yclicali } \\
\text { Count }\end{array}$ & $\begin{array}{l}: \\
5)\end{array}$ \\
\hline & $\sigma_{x}$ & $\rho_{x, G D P}$ & $\sigma_{x}$ & $\rho_{x, G D P}$ & $\sigma_{x}$ & $\rho_{x, G D P}$ & $\sigma_{x}$ & $\rho_{x, G D P}$ & $\sigma_{x}$ & $\rho_{x, G D P}$ \\
\hline GDP & 2.78 & 1.00 & 2.67 & 1.00 & 0.38 & 1.00 & 2.62 & 1.00 & 2.81 & 1.00 \\
\hline Consumption & 1.53 & 0.95 & 1.46 & 0.99 & 0.29 & -0.85 & 1.71 & 0.94 & 1.47 & 0.95 \\
\hline Investment & 12.27 & 0.86 & 11.15 & 0.96 & 3.91 & -0.96 & 14.54 & 0.83 & 11.45 & 0.86 \\
\hline Remittance & 26.21 & -0.10 & n.a. & n.a. & 21.55 & -0.94 & 26.73 & 0.30 & 22.13 & -0.30 \\
\hline
\end{tabular}

Note: Data were expressed in logs and detrended using HP filter with $\lambda=6.25 . \rho$ is the pairwise contemporeneous correlation coefficient.

\subsection{Permanent changes in remittance flows}

Table 3 reports the effects of permanent changes in remittance flows. The baseline calibration is set at a remittance-GDP ratio of $4 \%$. The results reveal similarities with Annen et al. (2016). When steady state remittance-GDP ratio increase by one percentage point, the investment rate remains the same and the average propensity to consume rises by one percentage point. Each one percentage point increase in the steady state remittanceGDP ratio reduces GDP per capita by approximately $0.94 \%$. The net impact of remittance on disposable income is zero. This result suggests that permanent increases in remittance are consumed rather than invested. The intuition is that an increase in remittances produce a positive income effect, and since leisure is a normal good it rises and hours worked falls. The reduction in hours worked leads to a decrease in the levels of output, investment, and capital.

\subsection{Temporary changes in remittance flows}

Table 4 reports the simulated business cycle statistics. Column (1) reports the baseline simulation. Statistics generated by the model are consistent with business cycle stylized facts: investment and consumption are procyclical, investment is much more volatile than output and consumption, and trade balance is countercyclical. Remittance is acylical in the model which is consis- tent with the data for remittance recipients. However, the model does not do a good job in matching consumption volatility in the data. Column (2) reports business cycle statistics for the case where there are no remittance shocks. Similar to Annen et al. (2016), the business cycle statistics for variables other than remittances are similar with or without remittance shocks which suggests that remittance shocks are being crowded out by productivity shocks. This result is confirmed by switching off the productivity shock while keeping the remittance shock. In column (3) one can see that volatilities of output, consumption and investment drop significantly. Without productivity shocks, remittance shocks account for only around $10 \%$ of volatility in output at most. The relative strength of the productivity shock explains why remittance is ayclical in the model. Virtually all of the volatility in aggregate variables (other than remittance) is explained by the productivity shock.

In the benchmark calibration remittance was assumed not to be related to the productivity shock and $\theta$ was set to zero. In columns (4) and (5) of table 4 a sensitivity analysis on $\theta$ was conducted. In column 4 the value of $\theta$ was set to 6.05 to produce a remittance-output correlation coefficient of 0.30 . Column 5 reports the simulation with $\theta$ set to -3.10 to produce a correlation of 0.30. Comparing columns (4) and (5) with the 
benchmark calibration in (1), except for the correlations, one can find very little difference in output volatility. As in Annen and Kosempel (2012), any cyclical relationship between remittance and output created in the model by changing the sign of $\theta$ does not reveal anything about a causal effect of remittance on output. It simply indicates that remittance levels are responding to the same variable causing output fluctuations.

The impulse responses of consumption, investment, output and hours worked to a positive one percent deviation from trend in the remittance level are shown in figure 4 . The income effect brought about by a one percentage deviation from trend in remittances leads to a decrease in hours worked, thereby leading to a decrease in output. However, since the remittance shock is temporary, agents optimally smooth their consumption profile inducing them to save. The rise in saving leads to an increase in investment, which in turn leads to a positive effect on output in future periods. It is important to note from these simulations that the impact of remittances to economic aggregates is very small in magnitude.

\subsection{Sensitivity analysis}

The impact of remittances is expected to be not uniform across countries and this is driven by three causes: First, some countries simply receive more remittances than others. For instance, the impact of remittances may be felt more in countries like Lesotho where remittances account for about $25 \%$ of their GDP. Raising the share of remittances to output by five times the benchmark of $4 \%$, the model predicts that output volatility will increase by roughly $13 \%$. This effect is rather small and is another confirmation that remittance shocks are being crowded out by productivity shocks.

Second, countries experience remittance shocks with varying degrees of persistence. According to $\mathrm{RBC}$ theory, the lower the persistence is the more immediate the impact of remittances on growth in output and the faster output is back again at trend. Lowering the persistence parameter to 0.33 (from the benchmark of 0.67 ), output volatility will peak at around 0.40 at three periods after the remittance shock and quickly goes back again to trend after 35 periods. On the other hand, raising the persistence parameter to 0.94 not only lowers the effect of remittances to GDP but it also increases the number of periods for GDP to be back again to trend (at 50 periods).
And third, remittances are more volatile in some countries than others. The model predicts that doubling the remittance volatility raises output volatility by about $25 \%$. Therefore, the impact of remittances may be felt more in countries that have high remittance volatility.

\section{Cross-country empirical evidence}

\subsection{Econometric specification}

This paper follows the econometric specification commonly used in the remittance effectiveness literature (see Chami et al. 2003 and Catrinescu et al. 2006). Formally, the following regression model was estimated for each country $i$ :

$$
g_{i, t}=\beta_{i}+\beta_{1} y_{i, 0}+\beta_{2} g c f_{i, t-1}+\beta_{3} w r_{i, t}+u_{i, t}(20)
$$

where $g$ is growth in real GDP per capita, $y_{0}$ is $\log$ of initial real GDP per capita, $g c f$ is the log of gross capital formation to GDP ratio, and $w r$ is the log of worker remittance to GDP ratio. The previous sections have shown that the distinction between temporary and permanent component of remittance is important. Hence, in some specifications $w r$ will be replaced with a component of remittance that is either temporary or permanent.

The next step is to come up with a measure of temporary and permanent remittance. In Annen and Kosempel (2012) they ran a regression model of the form:

$$
\ln q_{i t}=\varphi_{i}+\eta_{i} t+v_{i t}
$$

where $\ln q$ is the $\log$ variable of interest (GDP for instance) and $t$ is a time trend. Their approach makes use of the fitted value of the above regression as a measure for permanent value of $q$ and the error term becomes the temporary measure. However, if the fitted value and errors are used as regressors in another regression, the standard errors from the subsequent regression can suffer from a generated regressor bias. Pagan (1984) found that the foregoing two-step procedure can distort statistical inference. Thus, current study refrains from generated regressors and instead utilize the HP filter to generate the permanent and temporary component of remittance. From the theoretical model and simulations the hypothesis is that only temporary remittance was found to influence growth. If the hypothesis is true then by replacing $w r$ with $s$ the estimated coefficient for $\beta_{3}$ should be positive and significant. In contrast, 

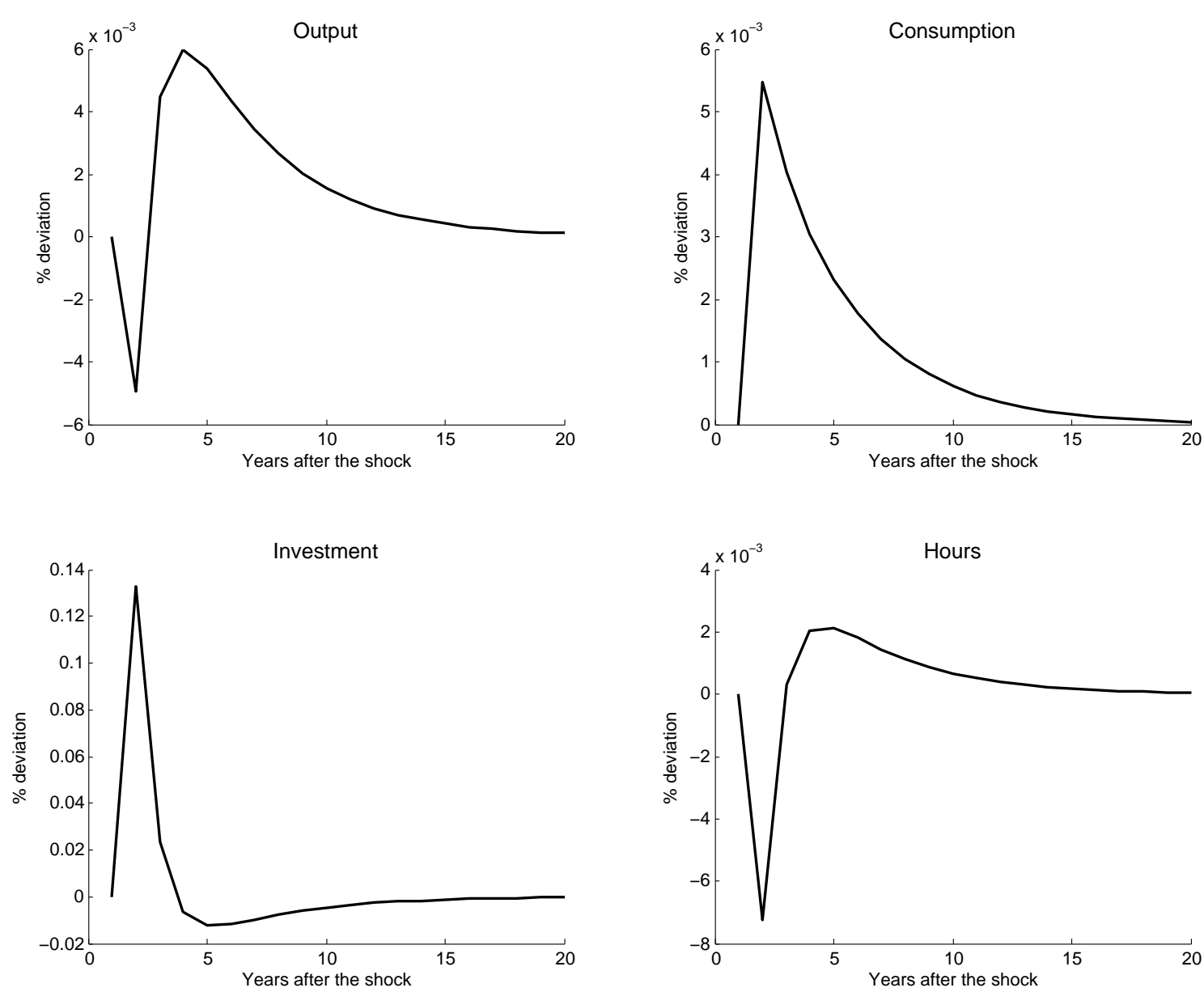

Figure 4: Impulse response to a one-percent remittance shock.

replacing $w r$ with $\tau$ the estimated coefficient for $\beta_{3}$ should not be statistically significant.

Panel data was constructed using 5-year averages from 1970-2012. Countries included in the sample as well as some descriptive statistics are presented in the Appendix. Data for gross capital formation was collected from WDI.

\subsection{Empirical estimates}

The results of the empirical analysis are presented in table 5. Columns (1)-(3) report estimates using OLS. The negative coefficients for log initial output suggest evidence for growth convergence. The estimates of the ratio of gross capital formation to GDP per capita are large and significant. Depending on the specification, around $24 \%-28 \%$ of the variation of growth is explained by the model using OLS.

Column (1) reports the model estimate in accordance with Chami et al. (2003). The estimated coefficient for the log share of remittances to GDP per capita is negative and not significant. This result essentially reveals that there is no significant correlation between the share of remittance to output and growth in GDP per capita, consistent with the results of Chami et al. (2003).

Column (2) reports the estimated coefficients with the permanent component of remittance. Similar to the result in column (1) there is no significant correlation between the permanent component of remittance and growth. Even the lagged permanent component is not significantly correlated with contemporaneous growth. These results are likewise consistent with RBC theory and confirm that growth effects of a permanent increase in remittance are difficult to detect from the data.

The results are different, however, if the permanent component of remittance is replaced with a temporary component. Shown in column (3) is the regression estimate with the temporary component. The estimated coefficient of the temporary component of remittance is positive and statistically significant (at $5 \%$ level). Lagged effect of temporary remittance is not significant. These results support the predictions of RBC theory that temporary fluctuations in remittances can influ- 
Table 5: Remittances and economic growth: Panel estimation (1970-2012).

\begin{tabular}{|c|c|c|c|c|c|}
\hline $\begin{array}{l}\text { Dependent Variable: } \\
\text { GDP Per Capita Growth }\end{array}$ & $\begin{array}{l}\text { OLS } \\
(1)\end{array}$ & $\begin{array}{l}\text { OLS } \\
(2)\end{array}$ & $\begin{array}{l}\text { OLS } \\
(3)\end{array}$ & $\begin{array}{l}\text { 2SLS } \\
(4)\end{array}$ & $\begin{array}{l}\text { 2SLS } \\
(5)\end{array}$ \\
\hline Log initial real GDP per capita & $\begin{array}{l}-0.007^{* * *} \\
(0.002)\end{array}$ & $\begin{array}{l}-0.005^{* *} \\
(0.002)\end{array}$ & $\begin{array}{l}-0.005^{* *} \\
(0.002)\end{array}$ & $\begin{array}{l}-0.005^{*} \\
(0.002)\end{array}$ & $\begin{array}{l}-0.005^{*} \\
(0.002)\end{array}$ \\
\hline Log gross capital formation/GDP (t-1) & $\begin{array}{l}0.034^{* * *} \\
(0.004)\end{array}$ & $\begin{array}{l}0.031^{* * *} \\
(0.004)\end{array}$ & $\begin{array}{l}0.032^{* * *} \\
(0.004)\end{array}$ & $\begin{array}{l}0.029 * * * \\
(0.004)\end{array}$ & $\begin{array}{l}0.030^{* * *} \\
(0.004)\end{array}$ \\
\hline Log remittance/GDP (t-1) & $\begin{array}{l}-0.009 \\
(0.017)\end{array}$ & & & & \\
\hline Remittance permanent & & $\begin{array}{l}0.004 \\
(0.002)\end{array}$ & & $\begin{array}{l}0.001 \\
(0.001)\end{array}$ & \\
\hline Remittance permanent (t-1) & & $\begin{array}{l}-0.003 \\
(0.002)\end{array}$ & & & \\
\hline Remittance temporary & & & $\begin{array}{l}0.047^{* *} \\
(0.015)\end{array}$ & & $\begin{array}{l}0.026 \\
(0.023)\end{array}$ \\
\hline Remittance temporary (t-1) & & & $\begin{array}{l}0.019 \\
(0.012)\end{array}$ & & \\
\hline R-squared & 0.24 & 0.27 & 0.28 & 0.26 & 0.26 \\
\hline F statistic & 10.97 & 10.85 & 11.21 & 9.72 & 9.53 \\
\hline Observations & 504 & 428 & 428 & 351 & 351 \\
\hline
\end{tabular}

ence economic growth.

It is possible, however, that these results are biased due to endogeneity of remittance. The model may not be able to properly identify the causal arrow from remittances to economic growth. For instance, a country performing poorly in terms of growth in GDP per capita may experience increased outward migration leading to more remittances sent back home. In this case, the OLS estimates presented earlier may be upward biased. To address the endogeneity concern a two-stage least squares (2SLS) regressions with lagged remittance and output as instruments were estimated. The results of 2SLS are shown in columns (4) and (5). The estimated coefficient for the permanent component remain positive and insignificant. On the other hand, the estimated coefficient for the temporary component remains positive and but is no longer significant. The estimated coefficient from 2SLS decreased substantially suggesting an upward bias in the OLS estimate.

\section{Conclusion}

This paper develops a simple RBC model augmented with stochastic remittance shocks. According to RBC theory, only worker remittances that are temporary in nature have an impact on GDP per capita in the long run. The in- tuition is that agents facing a temporary remittance shock will optimally save to smooth their consumption profiles. This smoothing behavior leads to a rise in investment and, consequently, output. On the other hand, permanent increase in worker remittances does not have an impact on GDP per capita. From the calibration exercise it was found that the contribution of remittance to output volatility is modest. An increase in the share of remittances to output brings very little impact to output volatility.

The predictions of the model were tested using panel data from 81 remittance recipient countries. A decomposition of remittance data in terms of permanent and temporary components was conducted. The regression results found that the temporary component of worker remittances have a positive impact to economic growth. Permanent component of worker remittances, on the other hand, does not have such an impact. These results are robust even if we account for possible endogeneity bias in the estimations.

The aforementioned results confirm the findings from the empirical literature that permanent wealth transfers, such as remittances, are not going to be very effective at raising output. 


\section{References}

Acosta, P. A., E. K. Lartey, and F. S. Mandelman (2009). Remittances and the Dutch disease. Journal of International Economics 79(1), 102-116.

Annen, K., M. Batu, and S. Kosempel (2016). Macroeconomic effects of foreign aid and remittances: Implications for aid effectiveness studies. Journal of Policy Modeling 38(6), 1136-1146.

Annen, K. and S. Kosempel (2012). On the effectiveness of foreign aid - A DGSE approach. Working Paper, University of Guelph.

Barajas, A., R. Chami, C. Fullenkamp, M. Gapen, and P. Montiel (2009). Do workers' remittances promote economic growth? . IMF Working Paper, WP 09153.

Baxter, M. and R. G. King (1995, February). Measuring business cycles approximate band-pass filters for economic time series. NBER Working Papers 5022, National Bureau of Economic Research, Inc.

Catrinescu, N., M. Leon-Ledesma, M. Piracha, and B. Quillin (2009). Remittances, institutions, and economic growth. World Development 37(1), 81-92.

Chami, R., T. Cosimano, and M. Gapen (2006). Beware of emigrants bearing gifts: Optimal fiscal and monetary policy in the presence of remittances. IMF Working Paper, WP 0661.

Chami, R., C. Fullenkamp, and S. Jahjah (2003). Are immigrant remittance flows a source of capital for development? IMF Working Paper, WP 03189.

Durdu, C. and S. Sayan (2010). Emerging market business cycles with remittance fluctuations. IMF Staff $P a$ pers 57(2), 303-325.

Faini, R. (2006). Migration and remittances: The impact on the countries of origin. pp. University of Rome. Available at: http://www.eudnet.net/download/Faini.pdf.

Fullenkamp, C., T. F. Cosimano, M. T. Gapen, R. Chami, P. Montiel, and A. Barajas (2008, March). Macroeconomic consequences of remittances. IMF Occasional Papers 259, International Monetary Fund.

Giuliano, P. and M. Ruiz-Arranz (2005). Remittances, financial development, and growth. IMF Working Paper, WP 05234.

Hodrick, R. J. and E. Prescott (1981). Post-war U.S. business cycles: An empirical investigation. Discussion Papers 451, Northwestern University, Center for Mathematical Studies in Economics and Management Science.

King, R. G., C. I. Plosser, and S. T. Rebelo (1988). Production, growth and business cycles : I. The basic neoclassical model. Journal of Monetary Economics 21(2-3), 195-232.

Kydland, F. E. and E. C. Prescott (1990). Business cycles: Real facts and a monetary myth. Quarterly Review, 318.

Mandelman, F. S. (2013). Monetary and exchange rate policy under remittance fluctuations. Journal of Development Economics 102(C), 128-147.

Mendoza, E. (1991). Real business cycles in a small open economy. American Economic Review 81(4), 797-818.

Nason, J. M. and J. H. Rogers (2006). The present-value model of the current account has been rejected: Round up the usual suspects. Journal of International Economics 68(1), 159-187.

Pagan, A. (1984). Econometric issues in the analysis of regressions with generated regressors. International Economic Review 25(1), 221-247.

Pallage, S. and M. A. Robe (2001). Foreign aid and the business cycle. Review of International Economics 9(4), 641-72.

Rajan, R. G. and A. Subramanian (2008). Aid and growth: What does the cross-country evidence really show? The Review of Economics and Statistics 90(4), 643-665.

Rand, J. and F. Tarp (2002). Business cycles in developing countries: Are they different? World Development 30(12), 2071-2088.

Rao, B. B. and G. M. Hassan $(2012,03)$. Are the direct and indirect growth effects of remittances significant? The World Economy 35(3), 351-372.

Ravn, M. O. and H. Uhlig (2002). On adjusting the Hodrick-Prescott filter for the frequency of observations. The Review of Economics and Statistics 84 (2), 371-375.

Sayan, S. (2006). Business cycles and workers' remittances: How do migrant workers respond to cyclical movements of GDP at home? IMF Working Papers 06/52, International Monetary Fund.

Schmitt-Grohe, S. and M. Uribe (2003). Closing small open economy models. Journal of International Economics 61(1), 163-185.

Schmitt-Grohe, S. and M. Uribe (2014). Open economy macroeconomics. Lecture Notes. 
Appendix: List of recipient countries and descriptive statistics.

\begin{tabular}{|c|c|c|c|c|c|c|c|c|c|c|}
\hline Country & $\sigma_{y}$ & $\sigma_{c}$ & $\sigma_{i}$ & $\sigma_{d}$ & $\rho_{y c}$ & $\rho_{y i}$ & $\rho_{y d}$ & Persistence & $\bar{d}$ & $g$ \\
\hline Algeria & 2.99 & 2.50 & 6.12 & 36.78 & -0.10 & 0.13 & 0.02 & 0.81 & 0.01 & 0.01 \\
\hline Antigua and Barbuda & 3.01 & 7.30 & 8.00 & 36.43 & 0.54 & 0.46 & 0.28 & 0.33 & 0.02 & 0.02 \\
\hline Argentina & 3.40 & 5.06 & 12.33 & 28.90 & 0.91 & 0.91 & -0.09 & 0.91 & 0.00 & 0.01 \\
\hline Bangladesh & 1.51 & 2.29 & 6.33 & 14.24 & 0.59 & 0.21 & -0.35 & 0.51 & 0.12 & 0.02 \\
\hline Barbados & 3.25 & 4.43 & 10.78 & 14.12 & 0.70 & 0.63 & 0.18 & 0.84 & 0.02 & 0.00 \\
\hline Belize & 2.36 & 3.18 & 11.78 & 10.80 & 0.62 & 0.26 & -0.34 & 0.86 & 0.05 & 0.03 \\
\hline Benin & 3.24 & 3.36 & 12.23 & 18.46 & 0.67 & 0.74 & -0.44 & 0.56 & 0.02 & 0.01 \\
\hline Bolivia & 1.05 & 1.61 & 13.80 & 29.08 & 0.58 & 0.16 & 0.09 & 0.78 & 0.04 & 0.00 \\
\hline Botswana & 3.92 & 3.57 & 15.15 & 18.69 & 0.44 & 0.77 & 0.00 & 0.72 & 0.00 & 0.04 \\
\hline Brazil & 2.53 & 2.44 & 7.08 & 28.70 & 0.87 & 0.87 & -0.14 & 0.86 & 0.00 & 0.01 \\
\hline Burkina Faso & 2.37 & 4.20 & 10.50 & 12.32 & 0.63 & 0.47 & 0.17 & 0.76 & 0.01 & 0.01 \\
\hline Cabo Verde & 2.02 & 1.69 & 8.20 & 7.06 & 0.02 & 0.79 & 0.05 & 0.59 & 0.15 & 0.04 \\
\hline Cameroon & 2.20 & 1.35 & 7.56 & 37.49 & 0.41 & 0.65 & -0.16 & 0.47 & 0.00 & -0.01 \\
\hline China & 2.62 & 2.32 & 2.32 & 25.55 & 0.58 & 0.58 & 0.10 & 0.62 & 0.01 & 0.09 \\
\hline Colombia & 1.45 & 1.31 & 8.58 & 23.84 & 0.92 & 0.80 & 0.04 & 0.69 & 0.01 & 0.02 \\
\hline Congo, Rep. & 3.69 & 4.68 & 16.75 & 94.76 & 0.16 & 0.00 & 0.32 & 0.41 & 0.00 & 0.02 \\
\hline Costa Rica & 2.49 & 2.76 & 12.08 & 23.76 & 0.93 & 0.76 & -0.37 & 0.66 & 0.01 & 0.01 \\
\hline Cote d'Ivoire & 2.89 & 3.73 & 30.12 & 12.15 & 0.52 & -0.27 & -0.18 & 0.78 & 0.01 & 0.00 \\
\hline Cyprus & 2.99 & 3.53 & 8.31 & 13.31 & 0.68 & 0.86 & 0.28 & 0.28 & 0.00 & 0.06 \\
\hline Dominica & 2.81 & 4.38 & 13.76 & 20.75 & 0.28 & 0.16 & 0.00 & 0.36 & 0.05 & 0.03 \\
\hline Dominican Republic & 2.61 & 3.31 & 8.83 & 19.49 & 0.74 & 0.65 & 0.11 & 0.45 & 0.06 & 0.03 \\
\hline Ecuador & 2.10 & 2.00 & 12.03 & 49.44 & 0.62 & 0.75 & -0.19 & 0.77 & 0.03 & 0.01 \\
\hline Egypt, Arab Rep. & 1.80 & 2.60 & 5.11 & 15.64 & 0.71 & -0.06 & 0.42 & 0.68 & 0.07 & 0.04 \\
\hline El Salvador & 2.37 & 3.08 & 10.56 & 19.89 & 0.95 & 0.81 & 0.64 & 0.29 & 0.16 & 0.01 \\
\hline Ethiopia & 4.60 & 5.19 & 11.21 & 32.37 & 0.81 & 0.36 & -0.20 & 0.67 & 0.01 & 0.02 \\
\hline Fiji & 2.60 & 3.48 & 11.57 & 18.52 & 0.50 & 0.57 & 0.34 & 0.72 & 0.04 & 0.00 \\
\hline Gabon & 4.29 & 8.18 & 15.84 & 39.91 & 0.23 & 0.70 & -0.03 & 0.50 & 0.00 & -0.01 \\
\hline Ghana & 1.88 & 4.65 & 14.45 & 48.04 & 0.29 & 0.37 & 0.36 & 0.37 & 0.00 & 0.01 \\
\hline Grenada & 4.10 & 6.57 & 11.44 & 22.89 & 0.55 & 0.73 & -0.38 & 0.71 & 0.04 & 0.04 \\
\hline Guatemala & 1.16 & 1.05 & 9.02 & 71.61 & 0.79 & 0.12 & 0.29 & 0.68 & 0.10 & 0.01 \\
\hline Guinea & 1.32 & 4.85 & 6.92 & 89.91 & 0.57 & 0.03 & 0.37 & 0.53 & 0.01 & 0.00 \\
\hline Guinea-Bissau & 4.98 & 4.24 & 25.99 & 16.11 & 0.64 & 0.57 & -0.32 & 0.45 & 0.05 & -0.01 \\
\hline Honduras & 2.07 & 2.04 & 12.35 & 28.28 & 0.23 & 0.25 & 0.24 & 0.77 & 0.16 & 0.01 \\
\hline India & 1.67 & 1.19 & 5.43 & 9.64 & 0.63 & 0.83 & -0.34 & 0.75 & 0.04 & 0.04 \\
\hline Indonesia & 2.63 & 2.19 & 8.85 & 24.87 & 0.80 & 0.89 & -0.29 & 0.34 & 0.01 & 0.03 \\
\hline Israel & 1.92 & 2.85 & 6.96 & 28.35 & 0.77 & 0.62 & 0.16 & 0.59 & 0.02 & 0.02 \\
\hline Jordan & 3.71 & 4.91 & 13.19 & 12.07 & 0.26 & 0.61 & 0.44 & 0.61 & 0.11 & 0.02 \\
\hline Kenya & 2.20 & 3.82 & 10.40 & 19.72 & 0.82 & 0.42 & 0.25 & 0.65 & 0.03 & 0.00 \\
\hline Korea, Rep. & 3.16 & 2.67 & 8.54 & 24.67 & 0.91 & 0.99 & -0.75 & 0.66 & 0.01 & 0.06 \\
\hline Lao PDR & 2.23 & 5.06 & 10.62 & 63.08 & 0.57 & -0.33 & 0.04 & 0.75 & 0.01 & 0.05 \\
\hline Lesotho & 3.91 & 3.47 & 9.87 & 10.75 & 0.54 & 0.21 & 0.23 & 0.64 & 0.25 & 0.03 \\
\hline Madagascar & 2.81 & 2.28 & 16.66 & 58.80 & 0.07 & 0.31 & 0.08 & 0.64 & 0.00 & -0.02 \\
\hline Malaysia & 2.67 & 2.98 & 10.58 & 16.08 & 0.87 & 0.92 & -0.15 & 0.74 & 0.00 & 0.04 \\
\hline Mali & 3.27 & 2.91 & 13.79 & 12.15 & 0.26 & 0.63 & 0.12 & 0.53 & 0.05 & 0.02 \\
\hline Malta & 2.08 & 2.67 & 8.08 & 15.59 & 0.64 & 0.34 & 0.29 & 0.74 & 0.00 & 0.06 \\
\hline Mauritania & 4.10 & 6.79 & 14.26 & 56.42 & 0.76 & 0.33 & -0.20 & 0.52 & 0.01 & 0.00 \\
\hline Mexico & 3.06 & 2.75 & 10.10 & 15.97 & 0.97 & 0.94 & -0.08 & 0.41 & 0.02 & 0.01 \\
\hline Morocco & 2.77 & 2.39 & 6.71 & 8.84 & 0.66 & 0.72 & -0.02 & 0.69 & 0.07 & 0.02 \\
\hline Mozambique & 2.99 & 3.91 & 13.57 & 22.62 & 0.67 & 0.21 & 0.19 & 0.69 & 0.01 & 0.02 \\
\hline Namibia & 2.99 & 3.34 & 15.95 & 4.88 & 0.25 & 0.71 & 0.07 & 0.74 & 0.00 & 0.02 \\
\hline Niger & 3.67 & 5.35 & 23.88 & 24.33 & 0.53 & 0.73 & 0.07 & 0.71 & 0.02 & -0.01 \\
\hline Nigeria & 4.31 & 8.58 & 15.20 & 52.51 & 0.60 & 0.46 & 0.14 & 0.65 & 0.08 & 0.00 \\
\hline Oman & 3.75 & 8.34 & 11.98 & 8.28 & 0.44 & 0.84 & 0.19 & 0.73 & 0.00 & 0.02 \\
\hline Pakistan & 1.21 & 2.51 & 4.33 & 15.72 & 0.63 & 0.19 & -0.39 & 0.80 & 0.06 & 0.02 \\
\hline Panama & 3.41 & 5.32 & 21.32 & 23.52 & 0.05 & 0.68 & -0.39 & 0.79 & 0.01 & 0.03 \\
\hline Papua New Guinea & 3.58 & 7.26 & 11.08 & 22.42 & 0.17 & -0.26 & 0.32 & 0.74 & 0.00 & 0.01 \\
\hline Paraguay & 2.56 & 2.85 & 6.45 & 18.46 & 0.07 & 0.53 & 0.18 & 0.82 & 0.02 & 0.01 \\
\hline Peru & 2.31 & 2.03 & 7.98 & 6.67 & 0.93 & 0.87 & 0.09 & 0.72 & 0.01 & 0.03 \\
\hline Philippines & 2.48 & 1.10 & 11.49 & 9.49 & 0.85 & 0.81 & 0.47 & 0.62 & 0.10 & 0.01 \\
\hline Rwanda & 11.19 & 3.66 & 17.53 & 41.54 & 0.48 & 0.75 & -0.32 & 0.65 & 0.03 & 0.02 \\
\hline
\end{tabular}

Notes: $\sigma$ is the standard deviation of the innovations in the stochastic process for output $(y)$, consumption $(c)$, investment $(i)$, and remittance $(d) . \rho$ is the pairwise contemporary serial correlations. Persistence is the estimated autocorrelation coefficient for remittances. $\bar{d}$ is the remittance to GDP ratio. $g$ is the growth rate of real GDP per capita. 
Appendix: List of recipient countries and descriptive statistics, continued.

\begin{tabular}{|c|c|c|c|c|c|c|c|c|c|c|}
\hline Country & $\sigma_{y}$ & $\sigma_{c}$ & $\sigma_{i}$ & $\sigma_{d}$ & $\rho_{y c}$ & $\rho_{y i}$ & $\rho_{y d}$ & Persistence & $\bar{d}$ & $g$ \\
\hline Samoa & 1.96 & 5.17 & 12.03 & 9.59 & 0.12 & 0.04 & 0.34 & 0.71 & 0.21 & 0.02 \\
\hline Senegal & 2.68 & 1.76 & 8.14 & 11.77 & 0.61 & 0.52 & 0.34 & 0.71 & 0.10 & 0.01 \\
\hline Seychelles & 4.05 & 6.77 & 25.65 & 86.46 & 0.57 & 0.79 & -0.22 & 0.60 & 0.02 & 0.02 \\
\hline Sierra Leone & 5.34 & 6.60 & 20.55 & 84.21 & 0.82 & 0.14 & 0.10 & 0.59 & 0.02 & 0.01 \\
\hline South Africa & 1.46 & 1.58 & 5.34 & 11.88 & 0.93 & 0.75 & 0.00 & 0.72 & 0.00 & 0.02 \\
\hline Sri Lanka & 2.07 & 1.61 & 7.62 & 10.07 & 0.35 & 0.78 & 0.67 & 0.78 & 0.10 & 0.04 \\
\hline St. Kitts and Nevis & 2.84 & 6.28 & 12.05 & 52.15 & -0.24 & 0.09 & 0.37 & 0.52 & 0.06 & 0.04 \\
\hline Samoa & 1.96 & 5.17 & 12.03 & 9.59 & 0.12 & 0.04 & 0.34 & 0.71 & 0.21 & 0.02 \\
\hline Senegal & 2.68 & 1.76 & 8.14 & 11.77 & 0.61 & 0.52 & 0.34 & 0.71 & 0.10 & 0.01 \\
\hline Seychelles & 4.05 & 6.77 & 25.65 & 86.46 & 0.57 & 0.79 & -0.22 & 0.60 & 0.02 & 0.02 \\
\hline Sierra Leone & 5.34 & 6.60 & 20.55 & 84.21 & 0.82 & 0.14 & 0.10 & 0.59 & 0.02 & 0.01 \\
\hline South Africa & 1.46 & 1.58 & 5.34 & 11.88 & 0.93 & 0.75 & 0.00 & 0.72 & 0.00 & 0.02 \\
\hline Sri Lanka & 2.07 & 1.61 & 7.62 & 10.07 & 0.35 & 0.78 & 0.67 & 0.78 & 0.10 & 0.04 \\
\hline St. Kitts and Nevis & 2.84 & 6.28 & 12.05 & 52.15 & -0.24 & 0.09 & 0.37 & 0.52 & 0.06 & 0.04 \\
\hline St. Lucia & 2.80 & 6.13 & 8.98 & 41.64 & 0.31 & 0.82 & -0.22 & 0.18 & 0.03 & 0.03 \\
\hline St. Vincent and the Grenadines & 2.52 & 5.97 & 7.53 & 40.33 & 0.59 & 0.61 & -0.08 & 0.41 & 0.04 & 0.04 \\
\hline Sudan & 2.48 & 5.89 & 22.09 & 40.84 & 0.85 & 0.18 & -0.39 & 0.60 & 0.01 & 0.01 \\
\hline Suriname & 7.11 & 26.27 & 20.66 & 76.08 & 0.73 & -0.16 & 0.18 & 0.47 & 0.00 & 0.01 \\
\hline Swaziland & 3.38 & 6.12 & 36.76 & 12.15 & 0.23 & 0.52 & 0.40 & 0.86 & 0.01 & 0.01 \\
\hline Syrian Arab Republic & 3.43 & 5.33 & 9.48 & 34.57 & 0.76 & -0.02 & -0.09 & 0.47 & 0.02 & 0.01 \\
\hline Thailand & 2.47 & 2.40 & 11.19 & 15.45 & 0.78 & 0.84 & 0.05 & 0.78 & 0.01 & 0.04 \\
\hline Togo & 3.75 & 4.76 & 25.44 & 19.91 & 0.50 & 0.75 & 0.41 & 0.82 & 0.09 & -0.01 \\
\hline Trinidad and Tobago & 4.11 & 9.02 & 12.92 & 42.84 & 0.30 & 0.34 & 0.02 & 0.57 & 0.01 & 0.03 \\
\hline Tunisia & 1.60 & 1.18 & 6.35 & 6.93 & 0.67 & 0.82 & -0.33 & 0.76 & 0.05 & 0.02 \\
\hline Turkey & 2.92 & 3.35 & 11.95 & 17.62 & 0.88 & 0.62 & -0.20 & 0.93 & 0.00 & 0.02 \\
\hline Vanuatu & 3.59 & 2.64 & 10.72 & 36.48 & 0.70 & 0.15 & 0.05 & 0.63 & 0.03 & 0.02 \\
\hline Venezuela, RB & 4.53 & 4.46 & 22.39 & 39.46 & 0.92 & 0.94 & -0.22 & 0.58 & 0.00 & 0.01 \\
\hline Yemen, Rep. & 3.32 & 4.32 & 9.06 & 10.98 & 0.29 & 0.62 & -0.13 & 0.71 & 0.04 & 0.02 \\
\hline
\end{tabular}

Notes: $\sigma$ is the standard deviation of the innovations in the stochastic process for output $(y)$, consumption $(c)$, investment $(i)$, and remittance $(d) . \rho$ is the pairwise contemporary serial correlations. Persistence is the estimated autocorrelation coefficient for remittances. $\bar{d}$ is the remittance to GDP ratio. $g$ is the growth rate of real GDP per capita. 